\title{
Political rights and multilevel citizenship in Europe
}

Paper prepared for the European Union Studies Association, Tenth Biennial International Conference, 17-19 May, Montreal, Canada, Panel 10B Dimensions of European Citizenship

\author{
Jo Shaw, \\ School of Law, \\ University of Edinburgh, \\ Old College, \\ South Bridge, \\ Edinburgh, \\ EH8 9YL \\ United Kingdom \\ jo.shaw@ed.ac.uk
}

Draft, not for citation 


\section{The emergence and nature of a multi-level citizenship regime in the European Union}

In the EU, it is now well established that the various regimes of rights enjoyed by citizens are dispersed across the national and supranational levels. This is an empirical and not a normative observation, and it is not intended to pre-empt any further discussion about the theoretical possibility of a true 'supranational citizenship' in a world of nation states. But in fact, empirical observation shows that even in the sensitive arena of political rights, a multi-level system of rights allocation exists. Articles 19(1) and 19(2) EC interfere, in respect of municipal and European Parliamentary elections respectively, with the sovereignty of the Member States, by requiring that the states respect the equal treatment right of a citizen of the European Union (i.e. a national of one of the Member States) to vote and stand as a candidate under the same conditions as nationals when resident in a Member State of which she is not a national.

So far as it is possible and reasonable to treat the EU as an emerging polity which has (at least descriptively speaking) some federal features, this dispersion of political rights across political levels is not really surprising. The EU's treatment of electoral rights for non-national EU citizens is an important element of an overall package of measures concerned with intra-EU migration, drawing upon not only Articles 17-22 $\mathrm{EC}$, but also the other treaty provisions which deal with the free movement of persons, and a variety of secondary legislative instruments (notable the Citizens' Rights Directive of $2004^{1}$ ). While it has long been one of the EU's raisons d'être as part of the internal market project to ensure the equal treatment of nationals of other Member States as privileged foreigners (or so-called second country nationals) in the host Member State, the EU has also increasingly taken on a role in relation to aspects of the movement of third country nationals into and across (and out of) the Member States, not least by creating a Schengen Borders Code and a Schengen Visa and Information System applicable most of the pre-2004 Member States. Stretching the limited competences conferred upon it by the Treaty of Amsterdam in this domain also into the realm of post-admission settlement and integration, the EU has adopted a

$1 \quad$ European Parliament and Council Directive 2004/38 on Citizens’ Rights, OJ 2004 L158/77. 
Directive on long term resident third country nationals, ${ }^{2}$ in which it has enacted a limited principle of non-discrimination for the benefit of groups of third country nationals who satisfy a minimum period of residence within the Member States. These developments highlight the extent to which the EU may be faced, in the future, with further challenges relating to the division of competences in relation to questions of immigration.

Within all federations, there are lively debates about which level of government should regulate immigration issues. ${ }^{3}$ The key question is whether immigration is an exceptional case (because of the link to the security of the state and to international diplomacy) or whether it should, in federal systems, be dealt with under the same public law principles and arguments about policy efficiency and legitimacy which govern the allocation of powers between different levels of government in other cases. Whatever approach is chosen, it is worth noting the following empirical observation about the pressures upon states, whether federal or unitary, in relation to immigration issues, especially (but not only) post-admission issues of social and political inclusion. Both sub-state regions, which often view themselves and/or are treated as stateless nations within wider multinational states, and cities, which often regard themselves as transnational rather than national actors, are important actors in this context. Cities, in particular, may be the chosen destinations of immigrants, rather than countries as such, not least because newly arrived immigrants often wish to join an established community in the host state of co-ethnics or co-nationals the presence of which conditions the process of post-admission inclusion (DeVoretz, 2004; Bauböck, 2003). A range of questions about migration and citizenship policies and practices can thus arise once the state is disaggregated in this way, particularly but not only in federal states, and especially in relation to the implementation of national, state-level policy decisions on immigration (Green, 2004: 12-18).

In this context it is important to distinguish between different aspects of the overall immigration 'package'. A case can be made for locating aspects of control at different levels of government:

Council Directive 2003/109/EC, OJ 2004 L16/44.

For the discussion on immigration federalism, see generally Schuck, 2002; Huntington, 2007; Spiro, 2001; Boushey and Luedtke, 2006. 
1. The management of borders and border controls, and rights of entry and residence. These matters are the traditional stuff of state sovereignty, and they also bring into play relations under international law with other states, including neighbours and sending states. In the EU context, the situation is complicated by the requirements imposed by virtue of EU law on the Member States, and the interface with the internal market, and under the EC Treaty many of these matters are now regulated by EU law.

2. While the rules on legal and illegal entry and residence in the state are nearly always set by the state, in practice the enforcement of such rules may sometimes be managed, on a delegated basis, by subnational and local authorities.

3. Furthermore there are some cases (notably Canada), in which economic migration choices (how many migrants? what types of migrants? under what conditions? etc.) are managed in a decentralised way, partly in order to facilitate recognition of the specificities of one province (Quebec) in relation to its migration requirements and partly in order to create a better balance across the rest of Canada of the demand for and supply of labour.

4. Moving to the post-admission dimensions of immigration, one can distinguish between the initial reception conditions (e.g. access to education, housing, health care and social services support), where services are usually delivered at the local level, and are sometimes delivered under conditions where entitlements decided at the local or the regional level rather than the national level, and longer term settlement and integration issues.

5. In relation to these latter issues, these range from welfare and social rights granted on the basis of residence, to issues which involve political rights and civil liberties, as well as the ultimate question of citizenship acquisition. In many states, there is, here, a blend of centralised state regulation, and regional and local variation, especially in relation to the delivery and implementation of rights. In some limited cases, there are variations in entitlements and access conditions for immigrants.

Concentrating on those aspects of immigration which relate to post-admission integration and longer term residence and settlement, it can be argued that one of the 
sites of contestation over immigration questions concerns citizenship, or the quality and nature of polity membership. Thus questions arise about how best to handle the organisation and dispersal of citizenship rights and citizenship practices across several levels - the supranational, the national, and the regional and local. The paper which follows builds upon a recently completed a study in which I examined in particular how electoral rights at the EU level operate as a supplement to the national allocation of electoral rights to nationals and to non-nationals (Shaw, 2007). Specifically, the book looks in detail at the effects of Article 19 EC, which creates a nondiscrimination principle. Nationals of the Member States resident in a Member State other than the one of which they are a national may vote and stand in local and European Parliamentary elections in the host state, under the same conditions as nationals.

These rights, granted by EU law, operate in addition to a variegated package of rights granted by around half of the current EU Member States under national law. These comprise either electoral rights in respect of local elections granted to all nonnationals, including third country nationals, or - in the case of the UK - some electoral rights in national and 'regional' elections granted to a wider range of nonnationals (Irish and Commonwealth citizens; EU citizens in respect of 'regional' elections to the devolved assemblies). Typically, in those Member States that grant them, electoral rights for non-nationals are used as part of a pathway to closer integration of immigrants and their families. Local electoral rights provide a taster of political participation, leading to closer integration, and in turn encouraging immigrants on the pathway to citizenship acquisition. Viewing electoral rights, including local electoral rights, as the reward for integration already achieved is the proper construction to be placed upon the choices of those states which grant electoral rights only after citizenship acquisition. There is no 'hard' EU law governing the allocation of electoral rights to resident third country nationals at the national level, but there is soft law encouragement which might in the longer term crystallize into 'harder' legal obligations on the Member States. For example, Working with the National Contact points within the context of the funding programme INTI, ${ }^{4}$ DG

$4 \quad$ See http://europa.eu.int/comm/justice home/funding/inti/funding inti_en.htm: 'This is an EU funding programme for preparatory actions promoting the integration in the EU member states of people who are not citizens of the EU. Its aim is also to promote dialogue with civil society, 
Justice and Home Affairs collaborated with the Migration Policy Group, an NGO offering expertise in the area, to produce a Handbook on Integration for policymakers and practitioners, which it is intended to update at regular intervals, which seeks to establish best practice, drawn from examples across the Member States, in areas such as initial reception of immigrants and civic participation. ${ }^{5}$ This Handbook encourages Member States to extend political rights to third country nationals:

'The representativeness and democratic legitimation of policies is enhanced by extending formal political rights to immigrants. Where political rights exist, they need to be put into practice with commitment from all sides including political parties...At the local level in particular, electoral rights provide immigrants with political representation in decisions that affect their most immediate interest...Governments should grant electoral rights to all residents at least at local level and minimise obstacles to the use of these rights, such as fees or bureaucratic requirements. Immigrants can be encouraged to make use of electoral rights through information campaigns and capacity building, relying in particular upon the networks offered by immigrant organisations.'

More diffuse support along the same lines can be found in the Common Basic Principles for Integration adopted in the form of Council Conclusions in November 2004. ${ }^{6}$ Principle 9 states:

'The participation of immigrants in the democratic process and in the formulation of integration policies and measures, especially at the local level, supports their integration.'

This stops short of explicitly recommending that the Member States institute local electoral rights for third country nationals. Amplifying these Common Basic Principles in a subsequent Communication on the integration of third country nationals, ${ }^{7}$ the Commission repeated some of the text of the Handbook on Integration regarding the benefits of democratic participation and encouraging immigrants to use

develop integration models, seek out and evaluate best practices in the integration field and set up networks at European level...'

5 DG Justice, Freedom and Security, Handbook on Integration for policy-makers and practitioners, (Brussels: European Communities, 2004).

$6 \quad$ Conclusions of the Council and the Representatives of the Governments of the Member States on the establishment of Common Basic Principles for immigrant integration policy in the European Union, Doc. 14776/04 MIGR 105, 18 November 2004.

7 A Common Agenda for Integration Framework for the Integration of Third-Country Nationals in the European Union, COM(2005) 389, 1 September 2005. 
electoral rights, but likewise stopped just short of explicitly encouraging the Member States which do not have such rights to adopt them.

In terms of the analysis of the patterns of local electoral rights, the question at issue in this paper is that it is not just supranational 'citizenship' (i.e. EU electoral rights or indeed the emerging pattern of EU regulation of the status of third country nationals) which helps to determine the package of political rights and claims which those who lack the badge of formal national citizenship can assert against the host state, but also (potentially at least) subnational 'citizenships', where differentiated political systems at the regional or the subnational level give rise to contestations between political authorities within, as well as across, states in relation to non-nationals' rights. The objective of this paper is not to provide answers about where political authority ought to be located in relation to the determination of the boundaries of the suffrage, but rather to look at some examples of active contestation across levels of government in both federal and unitary states in order to identify some key typologies which mark such contestations. In fact, at the present time there are not (yet) any concrete examples within the EU Member States of regional disparities in relation to electoral rights, ${ }^{8}$ although there are some disparities within the UK, because one type of election, namely elections to the devolved parliaments/assemblies of Scotland, Northern Ireland and Wales, simply does not exist in every part of the state. The issue, therefore, is (a) whether there exist current tensions which could be played out, in the longer term, in a more differentiated pattern of electoral rights across subnational regions or between cities, and (b) whether subnational tensions could have a discernible impact upon the development of national policies.

This paper uses the case of the contestation of electoral rights for non-nationals across the multiple layers of the complex 'euro-polity' as one example of a set of broader questions about the transformation of the nature of citizenship in contemporary Europe. In methodological terms, it is worth noting that law and legal institutions are here recognised as both reactive and proactive 'forces', structuring certain aspects of institutional change, but also as forces which themselves are in turn susceptible to change as a result of the political pressures. In practice, these are constitutional

$8 \quad$ The best examples can be found in Canada, Australia and Switzerland. The possibility for variation by locality or region has recently been opened up in Italy: see below. 
questions for a polity, in so far as the issue is one of the structural and ideological foundations of polities including the question of membership. The approach shares much in common with the methodological approach of 'constitutional ethnography', most associated with the work of Kim Lane Scheppele. Scheppele (2004: 395) describes constitutional ethnography as

'the study of the central legal elements of polities using methods that are capable of recovering the lived detail of the politico-legal landscape.' Its goal is not prediction, in the social scientific sense, but comprehension; 'not explained variation but thematization' (Scheppele, 2004: 391; emphasis in the original). It allows constitutionalism, as a result, to emerge

'as a set of practices in which the transnational ambitions of legal globalization flow over and modify the lived experience of specific local sites, and as a set of practices in which local sites inescapably alter what can be seen as general meanings' (Scheppele, 2004: 394).

It is the nestedness of multi-layered polities (subnational, national, supranational) within the broader legal framework of European integration, and the opportunities and constraints that this complex layering offers which is the primary focus of attention.

\section{Contesting electoral rights at the subnational level in the multi-level 'euro-polity'}

This part of the paper focuses on the regional contestation of political rights within Member States of the EU, looking at examples drawn from the UK, Spain, France, Italy, Austria and Germany. A sub-national territorial unit with autonomous or semiautonomous powers and institutions of government, such as Scotland, the German or Austrian Länder, the Spanish autonomous communities, or indeed the municipal authorities anywhere in the Member States, could seek to push the boundaries of the suffrage wider than they stand at national level for a variety of principled and instrumental reasons. In some cases, it may be because the party or parties controlling the relevant territorial unit differ sharply in ideology and approach to the national government, and they seek to use the opportunity of legal reform at the local or regional level in order either to emphasise their local 'difference' or to try to push for reform at the national level by showing an example of good practice. A form of intergovernmental intra-state competition can consequently emerge, and in that context it may well be decisive how exactly powers are divided according to the relevant 
constitutional settlement regarding local self-government or devolution, and which organ of the state has the decisive power to determine who decides. Competition between different levels of government has already been a characteristic feature of struggles over electoral rights for non-nationals in several states. The discussion begins by looking at the link between evolving notions of subnational identity (expressed in the context of stateless nations, for example) and possible re-definitions of the franchise at the subnational level. The focus then shifts to four states (of which three are large founding EU Member States) where there have in the last ten to twenty years been active campaigns, and or attempts, at the subnational or regional level to subvert restrictive national policies, through changes instituted by subnational authorities which seek to operate more inclusive policies towards non-nationals. In each case, the proposed changes have faltered, essentially because of constitutional restrictions. The paper takes a closer look at the cases of intrastate, intergovernmental competition which have occurred in this context. The chosen examples will make it possible draw some general conclusions about the different patterns of contestation occurring in this domain.

\section{a) UK (Scotland) and Spain (Andalusia) - territorial settlements and identity}

In the first two instances, the case for creating differentiated 'citizenship' and political rights for non-nationals at the subnational level can be seen as part of a broader set of contestations around as yet unsettled territorial and political settlements in the two states in question. Part of that identity may be expressed, or come to be expressed, through a self-conception as a space for migration which differs from the dominant national conception. Thus far, no legal changes have been instituted in the UK or Spain, but the paper examines the political and legal circumstances in which changes could occur.

Asylum has been a core battleground in relation to immigration autonomy in the UK. The UK is one of the many states which have used a policy of dispersing of asylum applicants, in the name of sharing the costs and the 'burdens' (Boswell, 2001). In practice, this has also meant that there have been some differences in the politicisation of asylum questions across states. In Scotland, for example, while immigration (and asylum) questions are reserved matters for the Westminster Parliament under the 
Scotland Act 1998, certain issues about the treatment of asylum seekers, and especially the forced removal of those who have been refused asylum, have been more heavily contested than in other parts of the UK. Since policy on children falls within the remit of the Scottish Parliament, moreover, political conflict has arisen as to whether so-called dawn raids to remove those who have been refused asylum from the United Kingdom are traumatic experiences which infringe the rights of the child, and whether such removal, however effected, would also be liable to deny the children certain basic rights, such as the right to an education. ${ }^{9}$ The issue has led directly to conflict between the Scottish Executive, involving a Labour Party-led coalition, and the Westminster-based UK Government, likewise led by the Labour Party. When the Scottish First Minister Jack McConnell sought some type of dispensation from the Home Office in London regarding the involvement of Scottish education and social service agencies in the decision regarding deportation and also its implementation, ${ }^{10}$ he was firmly rebuffed. In a political commentary in the Sunday Herald, a senior Scottish political commentator noted somewhat gloomily:

'If anything, McConnell's brush with the Home Office has confirmed that Holyrood's attempt to project Scotland as a welcoming place for foreigners is increasingly out of step with the clampdown implemented at Westminster. ${ }^{11}$

It is arguable that in other fields of immigration policy, while restricted in what it can do, the Scottish Executive has been a little more successful. Historically, like Ireland, Scotland has been a nation of emigration. This has involved principally emigration to the rest of the British Isles (including the island of Ireland, especially Ulster) and to North America and elsewhere in the British Empire/Commonwealth. According to David McCrone (2001: 101):

'Some two million people have left Scotland in the twentieth century, and at least similar numbers have done so in the previous century'.

Immigration was largely confined to inward flows from Ireland (especially Catholics - whereas it had been principally Protestants who had left Scotland for Ireland), Poles and Lithuanians especially after the second world war, Italians, and in more recent

\footnotetext{
9 'Protest over refugee dawn raids', BBC News, 17 September 2005, http://212.58.240.36/1/hi/scotland/4254490.stm.

'McConnell seeking asylum protocol', BBC News, 22 September 2005, http://news.bbc.co.uk/1/hi/scotland/4269894.stm.

'Holyrood Vs Westminster: the battle over asylum', Sunday Herald, 27 November 2005, http://www.sundayherald.com/53116.
} 
years the English. Scotland's population has declined severely as a proportion of the overall population of the United Kingdom (as Scotland's has dwindled to around 5 million, England's has continued to grow), and its population (and population profile) has continued to decline (and to age) because of declining fertility and insufficient immigration to match the continuing emigration.

One of the major initiatives of the Scottish Executive in the early years of managing devolved government after the first Scottish Parliament elections in 1999 was to promote positively the image of Scotland as a migration destination. This has included some specific initiatives which can be understood as exceptions to the generally restrictive UK policy, such as the Fresh Talent initiative giving overseas students who have completed university courses in Scotland two year visa extensions to work in Scotland, without need to seek a work permit. ${ }^{12}$ Clearly, this is hardly a radical departure from broader UK policy which likewise promotes a selective migration policy, focusing on migrants with specific skills especially in shortage areas or those with entrepreneurial tendencies, but it is a broader and less restrictive programme, aimed at ensuring that high qualified migrants remain in Scotland, perhaps long enough to acquire personal reasons to stay there permanently. In contrast, most UK-wide schemes permitting the employment of non-nationals are either limited to specific shortage occupations, where it is much easier for the employee and employer to obtain a work permit, or are limited to very narrow categories of 'Highly Skilled Migrants'. Furthermore, with its promotional and informational website Scotland Is The Place, ${ }^{13}$ which is also available in a Polish version under a separate '.eu' domain name, ${ }^{14}$ in recognition of the important role which Polish migrants have been playing in the Scottish economy since EU enlargement in 2004, the Scottish Executive is offering warm encouragement to migration to Scotland which is not matched by the equivalent UK-wide websites. ${ }^{15}$ On the contrary, the public face of the UK in relation to employment-related mobility

\footnotetext{
12 See the statement of First Minister Jack McConnell to the Scottish Parliament, 25 February 2004, http://www.scotland.gov.uk/News/News-Extras/191. Scottish Executive, New Scots: Attracting New Talent to Meet the Challenge of Growth, February 2004. http://www.scotlandistheplace.com/. http://www.szkocja.eu/. Compare the tone and focus of the Home Office's Working in the UK website: http://www.workingintheuk.gov.uk/working in the uk/en/homepage.html. A warmer tone is struck by a website of the British Council specifically focused at encouraging the mobility of researchers: http://www.britishcouncil.org/eumobility-networkuk-working-in-the-uk.htm.
} 
often demonstrates the increasing 'fortress mentality" ${ }^{16}$ which now appears to pervade much UK policy in relation to immigration, border controls, and the treatment of foreigners more generally.

While making electoral rights available to non-nationals is rarely likely to affect any migrant's decision-making in relation to choosing a destination (the Scotland Is the Place website promoting mobility to Scotland does not mention at all who can vote for the various political institutions it briefly describes), policy-makers may well regard them, as we have seen in this and the previous chapter, as useful parts of the broader toolkit of integration mechanisms. It is interesting to note that the UK already gives electoral rights to EU citizens to participate in 'regional' elections, notably the elections to the devolved political institutions in Northern Ireland, Scotland and Wales, as well as in the direct elections for the Mayor of London. Technically this is because such elections are governed within a framework analogous to local elections for the purposes of the franchise and so the right to vote flows naturally from that conclusion. ${ }^{17}$ Moreover, EU citizens were able to vote in the regionally based referendums in Scotland and Wales held to ascertain whether the people of these 'region-nations' wanted new forms of representation or political authority, and they have had the right to vote in every other referendum held since 1997 (e.g. the one held in London to decide whether to have a Mayor of London and a London Assembly) apart from the one held on the establishment of devolved institutions in Northern Ireland. $^{18}$

No other EU Member State proceeds in this manner in relation to electoral rights in 'regional' elections, although electoral rights are extended in a number of states, such as Hungary, Denmark and Sweden, to ‘county’ or 'provincial' level assemblies which

16 D. Orr, 'Open borders are the only alternative to the erection of a repressive fortress state', The Independent, 26 July 2006.

17 S.3(1) of the Local Government Elections Regulations 1995 (SI 1995, no. 1948) provides the basic amendments to the local electorate to incorporate the requirements of EU law, and in relation to the inclusion of EU citizens in the 'regional' franchise see s.17 of the Greater London Authority Act 1999; s.11 of the Scotland Act 1998; S.10 of Schedule 1 of the Government of Wales Act 1998; s.2(2) of the Northern Ireland (Elections) Act 1998. Ss.1(2) and 2(2) of the Referendums (Scotland and Wales) Act 1997. The parliamentary electoral register was used to determine the franchise in the Northern Ireland referendum, doubtless given the sensitivities of the issues attaching to this referendum, which followed on from the Belfast Agreement of Easter 1998. See generally House of Commons Library Standard Note, The franchise for referendums, Standard Note SN/PC/2583, 18 August 2003. 
are regarded, like the municipalities covered by Article 19(1) EC, as part of local selfgovernment (Waldrauch, 2005). In other Member States with federal systems of government, such as Germany and Austria, voting at the regional level is strictly reserved to nationals. The restrictive approaches in these states, which are grounded in a constitutional approach to the notion of the 'people', are charted in more detail later in this section.

Two questions might arise from this. One is whether other Member States with federal or quasi-federal arrangements might in the longer term choose to follow the UK in relation to the scope of EU citizens' rights. Clearly this question is closely related to the separate and important question of EU citizens' possible future voting rights in national elections (Shaw, 2007: Ch. 6). Here, the case of Spain seems to offer some potential for future developments, and Spain is examined at the end of this subsection, with reference back to how the UK case has developed.

The other question is whether, and if so how, the devolved parts of the UK might see a further widening of the suffrage to include third country nationals generally voting for the devolved Parliaments/Assemblies (or indeed local elections), even in the absence of more general UK-wide developments. I shall deal with this question first, with particular reference to the situation in Scotland.

The politicisation of debate about immigration and non-nationals in Scotland demonstrates that it could offer the type of environment in which arguments about developing a different franchise might occur. The status quo does not look positive, however. Section B3 of Schedule 5 to the Scotland Act 1998 lists the powers reserved to the Westminster Parliament after devolution, so far as pertains to elections. The list reads:

Elections for membership of the House of Commons, the European Parliament and the [Scottish] Parliament, including the subject-matter of-

(a) the European Parliamentary Elections Act 1978,

(b) the Representation of the People Act 1983 and the Representation of the People Act 1985, and

(c) the Parliamentary Constituencies Act 1986, 
so far as those enactments apply, or may be applied, in respect of such membership.

The franchise at local government elections.

This leaves very little competence at all for the Scottish Parliament in electoral matters, although the reference in the last line to local government elections means that the Scottish Parliament can make arrangements for local elections which deviate from the UK norm, and indeed it has done so recently in order to introduce proportional representation for Scottish local elections as of $2007 .{ }^{19}$ A broader commission (the Arbuthnott Commission) to look at the conduct of elections more generally in Scotland, including voter participation and the existence of several systems of voting was established not by the Scottish Ministers, but by the Secretary of State for Scotland - that is a Minister responsible to the Westminster Parliament. ${ }^{20}$ In sum, the Scottish Parliament is not permitted to change the franchise for any elections in Scotland, and could only be empowered to do so if the Scotland Act were amended. But at present there is no active political debate on this question, whether in Scotland or the wider UK, and so it is not foreseeable that such a change might occur in the near future. Depending upon the still uncertain outcome, in terms of a new Scottish Executive, of the elections held on 3 May 2007, change might occur in the medium to longer term. For example, it is conceivable that it could become coupled to the wider migration debate likely to develop under the framework of one or both of the Scottish Executive's Futures Project, ${ }^{21}$ or the Scottish Parliament's Futures Forum. $^{22}$

While any change would require primary legislation from the UK Parliament, there is no other constitutional bar to a wider franchise in Scotland. This point is reinforced by

$19 \quad$ Local Governance (Scotland) Act 2004.

20 A good deal of controversy occurred in the wake of the elections held in Scotland on 3 May 2007, which combined elections to the Scottish Parliament on the same day as local government elections. A large number of the votes cast in the Scottish Parliament elections were rejected by scrutineers, because a decision to include both the constituency vote and the regional vote on the same piece of paper appears to have given rise to confusion amongst voters. Many accusations about responsibility for the debacle, in which more than 100,000 voting papers (up to $5 \%$ of the total) were rejected, were leveled in the aftermath; the final decision on the nature of the voting paper appears to have been taken under reserved powers by the Secretary of State for Scotland, but only after consultation with the relevant parties at the Scottish level, who approved the new voting papers.

21 http://www.scotland.gov.uk/Topics/Government/futures/.

22 http://www.scotlandfutureforum.org/. 
the fact that the current arrangements permitting EU citizens to vote in such 'regional' elections in the UK are simply laid down in primary legislation making reference to the local government register. Section 11 of the Scotland Act provides:

(1) The persons entitled to vote as electors at an election for membership of the Parliament held in any constituency are those who on the day of the poll(a) would be entitled to vote as electors at a local government election in an electoral area falling wholly or partly within the constituency, and

(b) are registered in the register of local government electors at an address within the constituency.

From the point of view of electoral administration, this offers a certain degree of simplicity, especially since in 1999, 2003 and 2007 the Scottish Parliament elections were held on the same day as the Scottish local government elections. However, Scottish Parliament elections need not necessarily coincide with Scottish local government elections.

In fact, the current arrangement differs from that laid down in the Scotland Act 1978 for the abortive Scottish Assembly, an initiative which failed to win sufficient electoral approval in a referendum held in early 1979. Section 4 of the Scotland Act 1978 provided that the persons entitled to vote as electors at Assembly elections would be those who had their names on the register of parliamentary electors, plus peers (i.e. members of the House of Lords) on the local government electoral register. Peers are not entitled to vote in Westminster elections but they are entitled to vote in local government elections. ${ }^{23}$ Schedule 17 of the same Act laid down that the same groups of electors could vote in the referendum.

One might question why a changed definition of the franchise was used after 1997, both for the referendum and for the Scottish Parliament elections, ${ }^{24}$ and indeed the issue of the franchise was much discussed in both the House of Lords and the House

$23 \quad$ The Scotland Act 1978 was immediately repealed by the newly elected Conservative Government in 1979 after the failed referendum of 1 March 1979 contributed to the fall of the Labour Government soon thereafter. the Kilbrandon Report of 1973 (Royal Commission on the Constitution, 1969-1973, Cmnd. 5460), which was one of the main sources of inspiration when the devolution scheme of 1997 came to be put in place. 
of Commons in 1997, especially in relation to the question of who should vote in the referendum, as they would be the group effectively determining Scotland's constitutional status for the foreseeable future. ${ }^{25}$ Two key developments in relation to the local government and parliamentary registers between 1978 and 1997 should be noted: first, the presence of EU citizens on the former since 1993, and second, the presence of overseas (i.e. expatriate) voters on the latter. The latter were enfranchised by the Representation of the People Act 1983, as amended most recently by the Representation of the People Act 2000, to allow British nationals living overseas to register for up to 15 years after leaving the UK in the constituency in which they were last registered as residents.

Choosing the local electoral register as the basis for the franchise for elections in Scotland means a focus on residence within Scotland rather than any other form of affinity with Scotland. It not only avoided the question of the affinity and belonging of those 'expatriates' who had moved outside the UK within the last fifteen years, but also avoided the question of the participation 'rights' of the very much larger Scottish diaspora comprising those who had left Scotland within the last fifteen years in order to reside elsewhere in the UK. To what extent should the 'Scottishness' of either group of expatriates give them a say? Should the expatriates born in Scotland, who have chosen to emigrate whether within or outside the UK, be given a stake in the future of Scotland? Do they have a better right to participate, as indeed some might argue, than those English 'incomers' (i.e. those born and formerly resident in England, but now resident in Scotland)? It is not hard to see that such questions of affinity would be precisely those which a government committed to pushing through a referendum on a rather limited and localised concept of devolution in 1997 would want to avoid, given the presence of an active political movement for independence in Scotland. The parliamentary debates in 1997 reveal that the issue about expatriate voters was principally raised by members of the opposition Conservative party in order, perhaps, to muddy the waters about what the significance of a devolution referendum might be for the future of 'Scottishness' and of Scotland. Labour government ministers rather stressed that devolution was about residence and

$25 \quad$ For examples of debates, see House of Commons Committee stage of the Referendums (Scotland and Wales) Bill, House of Commons Hansard Debates for 3 June 1997, Cols. 247 to 278; House of Lords Debate, 3 July 1997, Hansard Debates, Cols. 321 to 344. 
localism. It is clear from those debates that issues about the scope of the franchise are clearly linked to questions of identity. This is also the case, as we shall see, in Spain.

In contrast to the UK, with its sui generis constitutional arrangements, if other states were to grant electoral rights in regional elections, whether to EU citizens or other third country nationals, this would normally require amendments to constitutional provisions. Some consideration has been given in Spain to widening the franchise in elections to assemblies in Spain's 17 regions or autonomous communities, but there exists a constitutional bar to extending electoral rights which would first need to be removed. Article 13(2) of the Spanish Constitution provides:

'Only Spaniards shall have the rights recognized in section 23 [i.e. the right to vote], except in cases which may be established by treaty or by law concerning the right to vote and the right to be elected in municipal elections, and subject to the principle of reciprocity.'

This text includes the constitutional reform adopted in August 1992 to give effect to Article 19 EC; this reform merely added the words 'and the right to be elected' to the paragraph.

It has been suggested by academics studying this issue at the University of Malaga that the constitutional limitation, allowing non-national voters only in municipal elections and not in elections in the autonomous communities, could be eliminated by removing the relevant words referring to municipal elections, thus leaving the matter to the various units of territorial governance to decide what approach they might like to take by adopting specific legislation under their various powers. ${ }^{26}$ However, in practice, any constitutional amendment is likely to face difficulties in Parliament. This is in large measure because the final territorial constitutional settlement in Spain, and especially the status of Catalonia, remains unclear. The conservative opposition Popular Party (PP) has expressed its opposition to any amendments to the Constitution, including an amendment to Article 13, at the present time; it remains unhappy about developments in relation to Catalonia, particularly in the wake of a referendum on 18 June 2006 which expressed clear public support for greater autonomy. In the absence of a constitutional change, the regional governments are

$26 \quad$ Participación política de los Extranjeros Residentes en Andalucía (PPERA). Propuestas de reformas constitucionales y estatutarias, http://campusvirtual.uma.es/in_en/ppera.htm. 
blocked from extending the range of electoral rights for non-nationals. Thus, for example, the regional government in Andalusia, which has expressed some interest in facilitating the political participation of non-nationals in regional political institutions, whether EU citizens or third country nationals, would be limited to other types of political participation initiatives such as elected foreigners' representatives with the right to make representations to the elected regional politicians.

However, assuming that the constitutional obstacle could be overcome, notwithstanding this negative prognosis, it is possible that regional electoral rights could be extended in the future to EU citizens at least in places like Andalusia; such a development would be most likely to garner broad public support, since it could linked into the generally still positive view in Spain about the role of 'Europe' generally. This positive view was expressed most recently in the lukewarm, but none the less positive result of the Spanish referendum on the Constitutional Treaty in March 2005. In terms of political prestige, it still carries weight for politicians and policy-makers to be seen as putting themselves in the vanguard of European developments, and from that point of view the possibility of pointing to the UK examples of EU citizens voting for representatives in devolved regional bodies represents a good example which can be referred to in public debate.

Moreover, there are also some examples of the mobilisation of EU citizens in the Spanish local elections, particularly amongst the retired communities in the south, not only in Andalusia, but also in nearby Murcia (Mendez Lago, 2005) which could indicate an 'appetite’ amongst such communities for the possibility of regional political representation. One group of EU citizens, including Spanish, British, German, Dutch, French and Belgian nationals, has sought to establish a new political party in one municipality, precisely for the purpose of promoting cross-national representation at the local level taking advantage of the availability of the EU electoral rights. ${ }^{27}$ However, UK-based political parties such as the Labour Party have also sought to foster political mobilisation at a local level in Spain, and John MacKay, the Secretary of the Labour International Costa Blanca North, wrote to a local expatriate newspaper to express his concerns about the dangers of 'ethnic-based'

$27 \quad$ See details of the new political party Nueva Javea at http://www.nuevajavea.com/en/index.html. 
politics if this sort of single issue party takes hold. His call was for the established Spanish parties to become more involved with the expatriate communities. ${ }^{28}$

The issue of third country nationals voting in regional elections would inevitably be a much more contested political issue in Spain. As regards local elections, it is already possible for third country nationals to vote under Article 13, providing treaties are negotiated (at the national level) with the relevant third countries (so far this is only the case with Norway), and local electoral rights are granted on a reciprocal basis. There are moves to extend this on a piecemeal basis, in support of a relatively broad consensus across both the PP and the PSOE (Socialist Party - in government since 2005) that local electoral rights could be an important element of a national integration programme for third country nationals. However, any move to remove or amend Article 13 of the Constitution to allow third country nationals to vote in regional elections could easily be interpreted by conservative political forces such as the PP as opening the door to allow Islamic voters to elect Spanish representatives.

While an Islamophobic cultural and political trend in the public sphere is undoubtedly visible in Spain, and is often associated with the increased recent immigration into Spain of Muslims especially from North Africa, this is not a unitary phenomenon, especially in the south of Spain. On the contrary, there are some political trends, especially associated with processes of sub-national identity formation in southern Spain, which seek to embrace more fully Spain’s Islamic heritage. Gunther Dietz (2004: 1088) argues, for example, that:

'Andalusia is undergoing a hasty process of sub-national identity building, which is motivated by an ethnicised tug-of-war of asymmetrical devolution and federalisation. Simultaneously, however, Andalusian regional society de facto is quickly 'multiculturalising' and pluralising in religious terms; this is mainly induced by North African immigration and the immigrant-support activities of local civil society movements and organisations.'

In broader ‘European’ terms, 'Andalusian identity has always been tempted to bridge the Mediterranean divide. Oscillating throughout different epochs between identifying itself as

28 Letter, Costa Blanca News, Issue 9-15 June 2006, http://www.costablanca-news.com/. 
the 'top' of the African and/or Oriental world or the 'bottom' of the Occident, its still recent integration into the European Union and its subsequent role as a European 'gate-keeper' at the margins of the continent is ambiguously redefining the region's self-perception' (Dietz, 2004: 1088).

This is complicated by the internal dynamics of Spanish devolution, where Andalusia looks for a space to define itself regionally and sub-nationally as not Castilian (and therefore different from Madrid), even though as a region it lacks the clear subnational identity focus which has driven the autonomy demands of the three northern regions of Galicia and, especially, the Basque country and Catalonia. The latter regions tend to see themselves as historic but currently stateless nations, mirroring a widespread view in Scotland. Andalusia cannot make such a claim, but it has at least been able to identify some limited features of its Maghrebian heritage, at least up to and probably beyond the reconquest of Spain around 1485, and re-incorporate these into the construction of a notion of Andalusian-ness, as part of its ultimately successful attempt to gain recognition as a historic region. Consequently, the process of devolution has proceeded in Andalusia at approximately the same pace as in the Basque country and Catalonia. In that context, the extension of electoral rights could operate in a positive synergy with the cultural encounters occurring on a continuing basis in the region between pro-immigrant NGOs, the immigrant communities, and more mainstream civil society organisations; this could not only bolster the possibility of integration, as defined and critiqued in this chapter, but also a more multicultural and hybrid regional or sub-national identity. Thus an identity-based approach could be a different way of conceiving of citizenship-related reforms such as electoral rights for non-nationals at the regional level as a form of intra-state, inter-regional or intergovernmental political competition.

\section{b) France and Italy - cities as laboratories?}

France and Italy are two large founding Member States of the EU where local electoral rights for third country nationals have not so far been granted despite longstanding political debate on the issue, but both of which are now grappling with large, and in some cases quite 'unintegrated' populations of immigrants or their descendants. In both cases, we see interesting example of subnational contestation of national policy, taking advantage of more favourable political conditions at the national level to try to advance the argument, or create a laboratory for learning. This 
is starting to bear fruit in Italy in particular, since the election of the current centre left government in 2006.

In the case of France, central to the definition of citizenship is a republican conception, linked to the nation defined in civic rather than ethnic terms (Brubaker, 1992; Lefebvre, 2003). Because of France’s approach to citizenship acquisition, large numbers of immigrants have either acquired citizenship through naturalization, or seen their children and grandchildren acquire it by birth. Thus when events such as the riots in the Parisian suburbs in 2005 and 2006 by unemployed young men of North African descent protesting their exclusion from the labour market are characterised by politicians as being problems generated by outsiders, this construction operates in denial of the fundamental legal principle that such persons, many of them French by nationality, are in fact already within the golden circle of the polity as nationally defined, with the right to vote. Hence, citizenship acquisition which gives the reward of full political membership does not always operate in practice to bring about socio-economic inclusion and membership, even though in both the German and Austrian cases, as we shall see, it is identified as the key or gateway to full integration. Meanwhile, the necessary constitutional amendment to start the process of bringing about local electoral rights for third country nationals remains on the table within the French legislature, consistently supported by forces of the political left, ${ }^{29}$ but so far unadopted. Initiatives within municipalities to organise local referendums on giving the right to vote to third country nationals have, like other subnational initiatives examined in this section, been declared illegal as outwith the competence of the relevant subnational authorities, ${ }^{30}$ but held on a consultative basis at the municipal level none the less. ${ }^{31}$

29 See the Socialist Party 'manifesto', Réussir ensemble le changement: Le projet socialiste pour la France, Part III, at 21: 'We will grant the right to vote in local elections to resident nonnationals who have been paying taxes for more than five years in our country', 1 July 2006, www.projet.parti-socialiste.fr. Judgment of the Tribunal Administratif Cergy Pontoise ( $1^{\text {st }}$ chamber) 23 February 2006, Préfet de la Seine-Saint-Denis, req. $\mathrm{n}^{\circ} 0511415$, reported and briefly noted in Bulletin Juridique des Collectivités Locales $n^{\circ}$ 4/06, 257.

31 A local consultative referendum was held on 26 March 2006 in the town of Saint-Denis; 31\% of the electorate participated, and $64 \%$ voted in favour of extending the right to vote to third country nationals. 
In Italy, meanwhile, although national citizenship acquisition is primarily framed by a model of family affinity (Arena, Nascimbene and Zincone, 2006), commentators postulate that problems of nation-building and political and economic modernization have left a weak residual link between citizenship and national identity (KoenigArchibugi, 2003). In relation to immigration policy development in Italy, commentators have frequently observed paradoxical moves: a broad public hostility both to immigration and to immigrants, but at the same time a willingness at various times to develop a more open immigration policy through recourse to mechanisms such as the regularisation of the status of those already residing in the state (Zincone, 2006). Italy also displays an interesting example of the intra-state competition emerging between different levels of government, again - as in France - involving political forces of the left. Local initiatives to give electoral rights to non-nationals developed in particular during the years of the centre right coalition government of Prime Minister Silvio Berlusconi (2001-2006), which saw few developments at national legislative level in relation to the rights of non-nationals and immigrants. On the contrary it saw a notorious tightening of immigration policy in the form of the Fini-Bossi law of 2002. However, these have come into conflict not only with less generous national policies on immigrants' rights but also with the limits of legal possibility as the law stands at the present time. Thus in August 2005, a Presidential decree struck down an amendment to the statute of the municipality of Genoa which would have allowed electoral rights to third country nationals, following advice provided by the Consiglio di stato in July 2005 to the effect that there was currently no legal basis in Italian law for such a development (Bencini and Cerretelli, 2005: 6). None the less, in an unlikely development in October 2003, the same Gianfranco Fini of the Fini-Bossi law put his political weight behind the proposition that third country nationals should have the right to vote in local elections in Italy, perhaps knowing that this was very unlikely to come to fruition under Berlusconi’s rightwing government. ${ }^{32}$ Indeed, it did not.

In an interesting twist, at the general election held in April 2006, Italy’s large expatriate vote was crucial in tipping the balance in a close election in favour of the centre left coalition led by former European Commission President Romano Prodi. It

32 E. Povoledo, 'Immigrants in Italy get unlikely aid on voting', International Herald Tribune, 17 October 2003. 
seems that this centre left coalition is much more open to suggestions for legislative change in relation to the electoral rights of non-nationals and immigrants at the national level. There would be a nice symmetry if the Italian expatriates were, in effect, to assist those expatriated from other states. The first signs were positive, with the Italian cabinet in summer 2006 approving a draft law, to be put before Parliament, reducing the waiting time for naturalization from ten years to five, and introducing birthright citizenship, following a similar model as that adopted in Germany in 2000, for the children of immigrants with settled residence in Italy. This followed a regularisation of illegal immigrants earlier in the summer based on a quota of 350,000 non-EU workers, and, in a related move concerning the transitional measures imposed on the workers from the EU8 Member States after May 2004, in mid July 2006 the Prodi government reversed the decision of the Berlusconi government to continue the transitional restrictions after the initial two year period, and opened Italy's labour markets fully to the EU8 workers. ${ }^{33}$

In early 2007, the way was opened for cities to adopt measures allowing for non EU nationals to vote in local elections to the 'circoscrizioni', as part of a package of draft changes to the underlying legislation governing local autonomy. If that draft were adopted, cities would be specifically empowered to act as laboratories for best practice, but only in relation to the lowest level of local government, the 'circoscrizioni' or districts, which are hierarchically inferior to the municipalities and which exercise no real powers. Article 2(4)(h) of the draft Nuovo Codice delle Autonomie, ${ }^{34}$ provides for the principle of

'riconoscere all'autonomia statutaria dei communi la possibilità di attribuire ai cittadini di Stati non appartenenti all’Unione Europea che siano titolari della carta di soggiorno di cui all'articolo 9 del decreto legislativo 25 luglio 1998, n.286, l'elettorato attivo e passivo nelle elezione degli organi delle circoscrizioni communali...' [recognise for local autonomous bodies the possibility of granting to citizens of states not belonging to the European Union in possession of residence cards under Article 9 of the legislative decree of 25 July 1998, active and passive electoral rights in respect of the elected bodies of the relevant district...]

33 'Italy drops barrier on EU labor', International Herald Tribune, 21 July 2006.

$34 \quad 25$ January 2007. 
If this approach were adopted, further developments in rights for non-nationals expressly depend at this stage upon the willingness of cities and other local communities to exercise their political autonomy in order to include third country nationals in the definition of the local electorate. However, in practice such a development would be entirely overtaken if the provisions on local electoral rights for third country nationals contained in the draft Amato-Ferrero law on immigration were adopted. This will remain uncertain until later in 2007, as it may be that as part of the negotiation and compromise process, the provisions - which are modelled on the relevant sections of the Council of Europe's Convention on the Political Participation of Foreigners in Local Life relating to electoral rights for third country nationals in municipal elections. ${ }^{35}$ Concluded in 1992, Italy is one of the relatively small number of Member States which have signed and ratified this Convention.

\section{c) Germany and Austria - intrastate competition in a federal state: pushing 'best practice'}

Finally, I want to discuss the cases of Germany and Austria. They have in common a number of issues. A denial, at least until recently, that they are 'countries of immigration'; a broadly ethnic definition of the citizenship; and a constitutional court which has been prepared to link a conception of the people to a concept of the demos, thus ruling out - as in France and Italy - subnational attempts at reform. However, the key characteristic of political organisation is that they are both federal states, and thus intrastate contestation takes on a particular legal form.

'Not a country of immigration' (kein Einwanderungsland) was the epithet used by successive German governments, almost to the present day, to describe a country which none the less has received large numbers of immigrants, especially since the second world war. However, for generations, German policy persisted in describing Turkish immigrants, even where they stayed long term, with their families and descendants, as 'guest workers' or 'Gastarbeiter', rather than immigrants. The implication was that their stay was temporary, not permanent. As Christian Joppke notes (Joppke, 1999: 62), 'this discrepancy between de facto immigration and its political denial is the single most enduring puzzle in the German immigration debate.'

$35 \quad$ ETS No. 144; opened for signature on 5 February 1992; entered into force 1 May 1997; www.conventions.coe.int/. 
Germany has raised 'the no-immigration maxim to a first principle of public policy and national self-definition'.

A second closely linked maxim relates to the treatment of the 'alien' or 'Ausländer' The fundamental principle of the German Ausländergesetz, the law which regulated the status of non-nationals until 2005, was the core definition of the alien as 'not German', and indeed this principle continues in the new Aufenthaltsgesetz under a different guise. This contrasts with an approach to alienage which constructs the nonnational as an 'immigrant', that is as someone who may be an incomer but who is subject to, and benefiting from, a set of reciprocal duties and rights, incumbent upon both the incomer herself and the receiving state in terms of a developing relationship. Instead the alien is constructed as the stranger - a potential danger to German society (Schmid-Drüner, 2006).

The relationship between these two principles is cemented by a third maxim, namely the ethno-cultural concept of German citizenship (Preuss, 2003), which has traditionally made the acquisition of German nationality by non-national immigrants, however they are defined or recognised in national law and politics, rather difficult, whilst at the same time facilitating access to national citizenship (and to the national territory) of those 'ethnic' Germans excluded by boundary changes at various points through the twentieth century (and even earlier). ${ }^{36}$ The requirements for citizenship acquisition were made rather less restrictive by a new nationality law which entered into force on 1 January 2000 (Hailbronner, 2006). ${ }^{37}$ However, it remains relatively difficult for resident non-nationals to naturalize on the basis of residence (an eight year qualifying period and renunciation of a former nationality except in very limited circumstances are required, as is the completion of other tests on language, etc.) and German law remains generally hostile to dual nationality except in limited circumstances where another state makes it literally impossible to renounce nationality, thus effectively cutting down the choices which can be made in relation to nationality acquisition by the descendants of those who have earlier migrated to

\footnotetext{
36 Around 15 million persons of German origin have settled in the Federal Republic of Germany since the second world war. They are not Ausländer in the sense of being 'not German', but rather Aussiedler (those from outside Germany settling in the historic motherland) and Übersiedler (literally ‘settlers moving across' from the former German Democratic Republic): Green, 2004: 4-5. Staatsangehörigkeitsgesetz (StAG) of July 15, 1999, Federal Law Gazette, vol. I, p. 1618.
} 
Germany but who wish to retains ties with the state of origin. The children of settled non-nationals do now acquire German nationality automatically if they are born in Germany (ius soli), but when they reach maturity such children must positively declare their intention to keep German nationality, or otherwise it will be lost when they are 23 (unless this renders them stateless). Even though the figures for nonnationals resident in Germany have shown a slight decline in numbers since 2000, from around $7.3 \mathrm{~m}$ to $6.7 \mathrm{~m}$ in 2005 (that is from 8.9 per cent to 8.1 per cent of inhabitants), it remains extremely high. ${ }^{38}$ This suggests only limited use of the naturalisation opportunities offered by the new law, although there has also been a decline in the number of non-nationals entering Germany in recent years.

Opinions remain divided amongst commentators about the political significance of one of the causes célèbres of the constitutionally based distinction between Germans and aliens. These were the rulings handed down in 1990 by the German Federal Constitutional Court, annulling as unconstitutional two legislative schemes introduced at the level of the Land by the states of Hamburg and Schleswig-Holstein which would have given electoral rights in local municipalities to non-nationals who satisfied certain types of criteria regarding residence and attachment (Rubio-Marín, 2000: Ch. 8; Benhabib, 2004: Ch. 3; Joppke, 1999: 104-119; Neuman, 1992; Béaud, 1992). ${ }^{39}$

However, legally speaking, the significance is clear. The Court relied upon a concept of popular sovereignty as the basis for political legitimacy, and linked this to a principle of a bounded Staatsvolk (or 'state people'), limited by reference to the holding of national citizenship. It explicitly rejected the principle of affected interests as the basis for a claim to political equality and access to the franchise. The key phrase reads:

'[the principle of popular sovereignty] in Article 20(2) of the Basic Law does not mean that the decisions engaging state authority must be legitimated by

\footnotetext{
$38 \quad$ See Migrationsbericht des Bundesamtes für Migration und Flüchtlinge im Auftrag der Bundesregierung (Migrationsbericht 2005), at 172.

39 BVerfGE 63, 37 (Schleswig-Holstein); BVerfGE 63, 60 (Hamburg), 31 October 1990.
} 
those who are affected by them; rather state authority must be based on a people understood as a group of persons bound together as a unity. 40 It extended its conclusion about 'state' authority also to the level of local democracy, holding that municipalities, like the elected authorities at the state and federal level, wield state power. Not only did this rule out the Hamburg and Schleswig-Holstein initiatives, but it also meant that the implementation of Article 19 EC subsequently required an amendment to Article 28 of the Basic Law. It makes it clear that any conceivable further steps towards the political inclusion of non-nationals would require further constitutional amendments. How far such amendments could go, and in particular whether EU citizens might conceivably be included in the national or even Land-level electoral franchise, is not obvious, since the ruling is premised on the central and unalterable norms of the German constitution about the nature of the state and its democratic legitimacy linked to the people. In any event, that latter issue is not a live one in Germany at present, but the question of enfranchising third country nationals certainly is, as we shall see below. In the shorter term, the Federal Constitutional Court pointed in the direction of the loosening of the rules on citizenship acquisition as the means of ensuring that in a more diverse Germany, with large numbers of persons not qualifying for German nationality under the historically restrictive conceptions which applied up to, and beyond, the date of reunification, pluralist political representation and voice is assured.

This is what prompted Seyla Benhabib to understand the Court's judgments as a 'swan song to a vanishing ideology of nationhood' (Benhabib, 2004: 207), but equally as the trigger for a set of 'democratic iterations' involving other political and legal forces such as political parties, groups representing immigrants in Germany, and the legislative organs of the state which have resulted in changes to the rules on the acquisition of nationality which came into force in 2000. This perhaps understates the rather fraught nature of the domestic political debates about the amendments to the laws on citizenship and national citizenship acquisition, which resulted in a more limited compromise law being adopted. More recently still, in rules which came into force in 2005, Germany belatedly adopted something approximating to an 'immigration law' for the first time, although it did so using not the term

40 BVerfGE 63, 37 at 50 (my translation). 
'Einwanderung', but rather a neologism developed for the purpose of avoiding that contested term: ‘Zuwanderung' (Bast, 2006: 3). This term literally means ‘movement towards', rather than 'into'. 'Migration’ rather than 'immigration'. The Zuwanderungsgesetz of 2004 was delayed from 2002 because an earlier text was annulled by the Federal Constitutional Court for reasons relating to the procedure followed in the Bundesrat, the Upper House of the German Parliament where the Länder are represented. The limitations of the texts which comprise the Zuwanderungsgesetz package and the difficulties which attended their adoption will be examined in more detail below. Germany’s ‘democratic iterations’ have indeed been extremely fraught at every turn in relation to issues of citizenship and immigration.

As noted above, Austria shares a number of characteristics in common with Germany in the field of nationality, citizenship and immigration. Not least amongst these have been the pervasive denial that Austria is an 'immigration country’ (König and Perchinig, 2003: 1; Jandl and Kraler, 2003), a basic attachment to an ethno-cultural concept of nationality, where the most common form of citizenship acquisition is via descent (ius sanguinis), rather restrictive, and often quite discretionary, conditions on naturalisation, and hostility to dual nationality. This latter point was actively supported by the ÖVP/FPÖ government:

'People with double citizenship can only be loyal with reservation. Double citizenship discriminated against Austrians, because they only had one citizenship, which will increase the danger of political conflict. Those who apply for Austrian citizenship should want to be integrated fully and not attach more importance to another land and there is no possibility of deportation for convicts. In my opinion two identities are impossible. ${ }^{41}$

Postwar reconstruction involved the development of Austria into a federal republic in which the nine Länder rather than the federal authorities administer nationality law. There are strong discretionary elements in the naturalisation process, and amendments introduced in 1998 were concerned with tidying up weaknesses in the current laws resulting from anomalies, such as whether a language test was required, and were not

$41 \quad$ Interview with Dr. Peter Mak, Ministerialrat, Austrian Ministry of the Interior, Vienna, June 2000. 
attempts to liberalise the laws. It did, however, also confirm the regular waiting period of ten years before naturalization and contributed to restricting the possibilities for more lenient application of discretionary naturalisation which had been practiced in Vienna (which is a Land as well as a City) and which had led to higher rates of naturalisation in this part of the country. In contrast to Germany, Austria has not introduced the ius soli principle for children born in Austria. Citizenship at birth is transmitted by descent, not place of birth, and the children of non-nationals born in Austria must wait for six years for naturalisation, although this is granted by entitlement not discretion. It is these dimensions of its nationality and naturalisation law and policy which marks Austria out as an exception to any putative European trend towards 'the harmonisation and liberalisation of citizenship acquisition by immigrants and their descendants’ (Bauböck and Çinar, 2001: 267). Even so, Rainer Bauböck and Dilek Çinar still maintained that it was not a conception of the nation as an ethnic community which drove such restrictive policies, but rather an attempt to close the Austrian welfare state off from 'strangers' to the maximum degree possible. This argument is harder to sustain after further amendments to nationality legislation which came into force in March 2006, which also institute a test requiring 'basic knowledge' of the 'democratic order and history of Austria and the respective federal province’ (Çinar and Waldrauch, 2006: 34). Dilek Çinar and Harald Waldrauch (2006: 35) conclude that the most recent amendments, which also include higher fees for naturalisation, restrictions on the naturalisation of foreign spouses, and changes to the conditions for facilitated naturalisations for certain groups, are 'inspired by the principle of 'integration before new immigration' that has been asserted since the late 1990s.'

Until the 1990s Austria experienced waves of migration that were partly associated with its geographical and geopolitical position as a transit country situated on the Iron Curtain, and were partly a result of its labour market requirements. Thus Austria, like Germany, recruited 'guestworkers', principally from the former Yugoslavia (SFRY) and Turkey. From the early 1990s onwards, labour migration was restricted with quotas imposed; these were gradually decreased, and after 2002, effectively abolished except for very highly paid workers, whose salary exceeded a minimum threshold. Immigration continued, throughout the 1990s and into the 2000s, on the basis of asylum applications, and also requests for family reunification, in particular as earlier 
waves of migrant workers who acquired Austrian citizenship through naturalization subsequently sought to bring in non-national spouses and other family members. After the creation of the first ÖVP/FPÖ coalition in 2000, the rhetoric moved to 'zero immigration', and to an emphasis on integration obligations upon non-nationals. Accordingly, since 2002 and an amendment to the Aliens Act (Fremdengesetz), all non-nationals who have entered Austria since 1998 are required to comply with an 'integration agreement', which means following courses especially in language skills which involve, since January 2006, some 300 hours of attendance. There was also a strong emphasis on security issues, and the ÖVP/FPÖ coalition agreement dealt with immigration and security issues under a joint heading (König and Perchinig, 2003: 35).

Against such a policy and legislative background, it is hardly surprising that electoral rights for non-nationals, beyond the confines of EU law, have rarely been on the political agenda in Austria. According to the SPÖ in 2000: 'Today there is simply not the political will to address the issue of voting rights at the national level' ${ }^{42}$ Nominally, the SPÖ might be expected to be in favour of widening the suffrage. Indeed, they admit that 'Our theoretical goal is close to the Greens, but in practice in the world of politics it is necessary to make compromises'. ${ }^{43}$ As the same interviewee indicated, the fear of losing political capital has restricted debate: 'Between 1989 and 1993, with over 120,000 immigrants in Vienna, no one within the SPÖ continued to talk about voting rights for third country nationals'. However, the SPÖ in Vienna was responsible for a more limited project to support the rights of third country nationals, in the form of the so-called Integration Fund. This latter body developed a model for the city whereby immigrants can vote for a representative body which is then able to consult with the municipal council. The Steering Committee for the Fund is the Kuratorium, established by the City. It issues guidelines for the Integration Fund and determines its tasks and goals. The Kuratorium is a body with 18 seats, of which three are reserved for migrants and NGOs. The Greens and the Liberals had wanted this to be seven. The Fund focuses on a diversity approach, rather than the management of

\footnotetext{
42 Interview with Robert Leingruber, International Secretary of the Austrian Social Democratic Party, Vienna, June 2000.

$43 \quad$ Franz Jerabek, Office of the Fund for Integration and assistant to SPÖ City Councillor and Member of the City Government, Renate Brauner, Vienna, June 2000.
} 
minorities, and its principal work is in the areas of social work, youth programmes and language courses (Krahler and Sohler, 2005: 21-27 and 50-56).

Matters changed somewhat in Vienna after the election of a new SPÖ Land and City government in 2002, which formed an agreement with the Greens on a number of matters including a commitment to introduce electoral rights for third country nationals (Perchinig, 2005). This brought to centre stage Renate Brauner, an SPD member who had long campaigned on the issue of electoral rights as City Councillor for Integration matters, but who had previously been a more marginal figure. Furthermore, an opinion poll amongst potential third country national voters conducted on behalf of Brauner and her colleagues indicated that $70 \%$ of potential third country national voters said they would use the vote if granted it (Krahler and Sohler, 2002: 52, referring to Jenny, 2002). This suggested that the vote in municipal elections for third country nationals could effectively be seen as part of a larger integration strategy, binding the non-nationals closer to the Austrian state and public authorities. Amendments were introduced to the relevant Viennese electoral laws to allow for voting by third country nationals with five or more years of residence in the Bezirksvertretungen. These community councils are the level at which EU citizens also participate in municipal governance within Vienna, since the Viennese city council doubles as a Land parliament and thus is excluded from the scope of the Article 19 voting rights. ${ }^{44}$ Such councils below the level of the city do not exist elsewhere in Austria, and indeed they are not mentioned at any point in the Austrian constitution. This raised the question of whether third country nationals voting in these elections was possible under Austrian constitutional law, since it is clear from the constitution that voting for Gemeinderäte (the normal level of municipal councils) is reserved for Austrian citizens, with an exception being made for EU citizens pursuant to an amendment to implement the Treaty of Maastricht (Article 117). ${ }^{45}$ It is universally agreed, moreover, that voting in national and Land level elections is also reserved for citizens.

44 Judgment of the Austrian Constitutional Court of 12 December 1997, B3113/96, B3760/96.

45 For brief notes on the application of Article 19 in Austria, see the regular national country reports for the EU Network of Experts on Fundamental Rights (CFR-CDR), most recently Nowak et al, 2005: 113. 
In seeking to exploit this constitutional 'space', the Viennese City Government found support for its approach from senior constitutional lawyers in Austria, including Professor Heinz Mayer of the University of Vienna (Mayer, 2002). He concluded that as the Viennese Bezirksvertretungen are regulated by law at the level of the Land rather than the federal state and exercise no legislative competences, they should not be regarded as general representative bodies, and as such are not subject to the principle under the constitution of the 'homogeneity of the franchise', which restricts the right to vote to in all elections to Austrian citizens. After the law was adopted in December 2002, it was subjected to a constitutional challenge before the Austrian Federal Constitutional Court by a number of members of the ÖVP and FPÖ parties sitting in opposition in the Viennese legislative body. The FPÖ, in particular, mounted a political campaign against the amendment, arguing that 'a registration form (i.e. proof of residence) is too little' for the right to vote, which should be reserved only for citizens. Its campaign included the use of posters displayed prominently in Vienna, indicating that as a party it does indeed have a multicultural view of the scope of Austrian citizenship, a view which does not necessarily chime happily with some of its other political pronouncements. However, the point of the campaign was the emphasise that to be a true 'Wiener' or 'Wienerin', regardless of colour or ethnic background, an immigrant had to become an Austrian citizen.

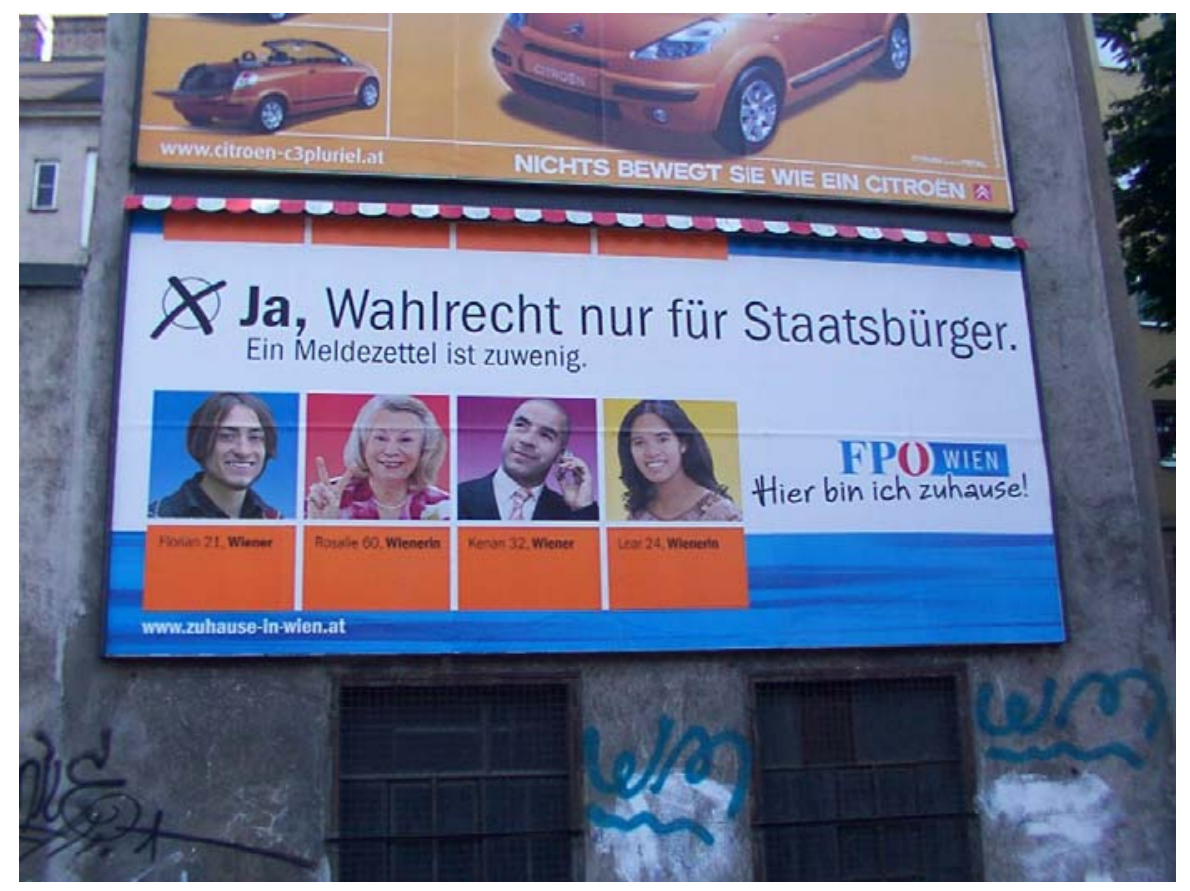

Photograph: Alfred J Thomas

Campaign Poster of the FPÖ displayed in Vienna during the summer of 2003. 
In the event, the Constitutional Court adopted a narrow interpretation of the constitutional possibilities under Austrian law, cutting off what had been put forward by proponents as a promising experiment to see whether third country national voting could contribute to the integration process in Austria (Nowak and Lubich, 2005: 80). As a matter of constitutional text and interpretation, ${ }^{46}$ the Court had no difficulty in first confirming that the electorate for national elections to the lower house of parliament (the National Council or Nationalrat), for regional elections to the legislatures of the Länder (Landtag), and for local elections to the municipal councils (Gemeinderat) is restricted in principle to Austrian citizens alone, subject to the requirements of Article $19 \mathrm{EC}$ which are referred to in Article 117 of the Constitution. However, this is not really an exception built into the Constitution as such, but rather a recognition of Austria's internal national perspective on European Community law, which is to recognise its supremacy vis-à-vis Austrian law, even the Austrian Constitution. It emphasised the principle of the 'homogeneity of the franchise' in this context, whereby each level of government should be voted for by an identically defined electorate. Drawing upon what might be described as the ethos of nineteenth century nationalism (Perchinig, 2005: 10), the Court decreed that the rules on the franchise for the national, provincial and municipal levels of government are merely a specific example of the general principle stated in Article 1 of the Constitution whereby 'Austria is a democratic Republic. Its law stems from the people.' This 'people' is the Austrian people, defined by citizenship. ${ }^{47}$

Recognising that Vienna's Bezirksvertretungen are not regulated by the Constitution but by state law, the Court none the less found that they are general representative bodies, in the sense that they are established by law to deal with matters in the public interest, not in the interests of particular groups or professions, and fulfil a function as representative organs of a defined territorial entity. Consequently, the principle of the homogeneity of the franchise must apply to them, even though in reality the 'people' or Volk which can vote for the Bezirksvertretungen, like the Gemeinderäte in the rest of the country, is constituted by Austrian citizens plus resident EU citizens from other Member States. Thus the Court gave no intrinsic weight to the re-definition of the

$46 \quad$ VfGH 30 June 2004, G218/03.
$47 \quad$ VfGH 30 June 2004, at 47. 
'people' in terms of the impact of EU law, other than to recognise the single exception mandated by Article 19 EC. It stated that the exception to Article 1 brought about in order to give effect to Austria's membership of the EU, whereby the law stems not only from 'the people', but also from the 'organs of the (European) Community', was 'irrelevant' in this context. ${ }^{48}$ Consequently, the Court annulled as unconstitutional the amendments to the Viennese law on municipal elections which would have allowed third country nationals with five years settled residence to vote in elections to the Bezirksvertretungen.

Of course, as Manfred Nowak and Alexander Lubich (2005: 80) point out, the Court was not bound to have limited itself to defining the 'people' for the purposes of the elections to the Bezirksvertretungen by reference to Article 1 of the Constitution, but rather it could have taken a different line in relation to the fact that these local bodies, which have very few powers, are not covered explicitly by the Constitution. If it had not concluded that these bodies are general representative bodies, it would not have felt itself obliged to apply the narrow concept of (Austrian) people to them. It is also notable that the Court hardly makes any reference to the contribution of EU law to undermining a unitary concept of 'the people', but rather it simply dismisses the relevance of EU law to deciding the issue in relation to other groups of 'non-people'. Bernhard Perchinig deplores the failure to refer to the development of concepts of citizenship in the EU context, including the notion that the rights and status of third country nationals resident in the Member States should be approximated as closely as possible to those of EU citizens resident in another Member State. In any event, the Court's narrow conclusion on the reach of a nationality-defined concept of the 'people' as sovereign means that the Bezirksvertretungen elections cannot become a laboratory within which the city authorities in Vienna could experiment with different participatory mechanisms to promote the integration of non-nationals, in addition to naturalized citizens who are already included in the franchise. Indeed, naturalization however difficult it remains - is the only route to political inclusion in Austria for third country nationals.

$48 \quad$ VfGH 30 June 2004 at 48. 


\section{Conclusions}

In terms of the different strategies followed by subnational units of government seeking to contest restrictive definitions of the franchise at the national level, two distinct themes can be seen.

Some subnational regions may be consciously creating a space for migration within the polity, either by competing for greater numbers or specific types of migrants. This may or may not be associated with reinforcing a distinctive territorial identity, particularly one which is articulated through an active diaspora engagement programme (e.g. Scotland). Alternatively, such a policy may be limited only to articulating a specific conception of how migrants 'fit' within the subnational territorial unit, although this may also be the case in relation to cities, such as Vienna or various municipalities in France and Italy, which have tried to implement a broader and more inclusive notion of the demos through the medium of local electoral rights attaching to residence rather than nationality.

The second theme concerns the question of 'best practice' and the role of intrastate or intergovernmental competition within the state. In this context, the city or the region may lay claim to acting as a laboratory for integration, or it may be seeking specifically to influence the development of policy at the national level. However, we have seen how often such attempts may fall foul of notions of a common 'national' citizenship which has restricted all attempts in EU Member States hitherto to develop local electoral rights for third country nationals through local or regional level action.

It must be recalled that it was not the objective of this paper to make the case for regional differentiation in electoral rights for non-nationals, or indeed to argue for a broader or narrower conception of the franchise. The point of the paper is essentially empirical rather than normative, to identify patterns of argument which are themselves part of iterative processes which link the various levels at which citizenship is formed and re-formed in the EU context. The role of what Benhabib terms 'democratic iterations' in the relationship between EU and national citizenship is now well established. The subnational level is just starting to be fully explored. 


\section{References}

Arena, M., Nascimbene, B. and Zincone, G. (2006) 'Italy’, in Bauböck et al, 2006b, 238-266.

Bast, J. (2006) 'The Legal Position of Migrants - German Report', Report Presented to the XVIIth International Congress on Comparative Law, Utrecht, 16-22 July 2006.

Bauböck, R. (2003) ‘Reinventing Urban Citizenship’, 7 Citizenship Studies 139-160.

Bauböck, R. and Çinar, D. (2001) 'Nationality Law and Naturalisation in Austria', in Hansen and Weil, 2001, 255-272.

Bauböck, R., Ersbøll, E., Groenendijk,K. and Waldrauch, H. (eds.) (2006) Acquisition and Loss of Nationality. Policies and Trends in 15 European states. Volume 2: Country Analyses, Amsterdam: Amsterdam University Press.

Béaud, O. (1992) 'Le droit de vote des étrangers: l'apport de la jurisprudence constitutionnelle allemande à une théorie du droit de suffrage', Revue française de Droit administratif 409-424.

Bencini, C and Cerretelli, S. (2005) Racism in Italy, ENAR Shadow Report 2005.

Benhabib, S. (2004) The Rights of Others, Cambridge, Cambridge University Press.

Boswell, C. (2001) Spreading the Costs of Asylum: A Critical Analysis of Dispersal Policies in the UK and Germany, Anglo-German Foundation Report 1314, London and Berlin, June 2001.

Boushey, G. and Luedtke, A. (2006) 'Fiscal Federalism and the Politics of Immigration: Centralized and Decentralized Immigration Policies in Canada and the United States', 8 Journal of Comparative Policy Analysis 207-224.

Brubaker, R. (1992) Citizenship and Nationhood in France and Germany, Cambridge, MA: Harvard University Press.

Çinar, D. and Waldrauch, H. (2006) 'Austria', in Bauböck et al, 2006, 9-40.

DeVoretz, D. (2004) Immigrant Issues and Cities: Lessons from Malmö and Toronto, Willy Brandt Series of Working Papers in International Migration and Ethnic Relations, 2/04.

Dietz, G. (2004) 'Frontier Hybridisation or Culture Clash? Transnational Migrant Communities and Sub-National Identity Politics in Andalusia, Spain', (2004) 30 Journal of Ethnic and Migration Studies 1087-1112.

Green, S. (2004) The Politics of Exclusion. Institutions and immigration policy in contemporary Germany, Manchester: Manchester University Press.

Hailbronner, K. (2006) 'Germany’ in Bauböck et al, 2006, 153-181.

Hansen, R. and Weil, P. (eds.) (2001) Towards a European Nationality. Citizenship, Immigration and Nationality Law in the EU, London: Palgrave.

Huntington, C. (2007) 'A Constitutional Roadmap for Immigration Federalism', University of Colorado Law School, Legal Studies Research Paper Series, Working Paper Number 07-06, March 6 2007, available from http://ssrn.com/abstract $=968716$

Jandl, M. and Kraler, A. (2003) Austria: A Country of Immigration?, Country Report, Migration Information Source for the Migration Policy Institute, available from www.migrationinformation.org, March 2003.

Jenny, M. (2002) Politische Partizipation von MigrantInnen in Wien. Erwartungen der Betroffenen an ein AusländerInnen-Wahlrecht, unpublished report, SORA, Vienna.

Joppke, C. (1999) Immigration and the Nation States. The United States, Germany, and Great Britain, Oxford: Oxford University Press. 
König, K. and Perchinig, B. (2003) 'Austria', in J. Niessen, Y. Schibel and R. Magoni (eds.), EU and US approaches to the management of migration, Migration Policy Group, May 2003.

Krahler, A. and Sohler, S. (2005) Active Civic Participation of Immigrants in Austria, Country Report prepared for the European research project POLITIS, Oldenburg 2005, www.uni-oldenburg.de/politis-europe.

Lefebvre, E. (2003) 'Republicanism and Universalism: Factors of Inclusion or Exclusion in the French Concept of Citizenship’ (2003) 7 Citizenship Studies 15-36.

McCrone, D. (2001) Understanding Scotland. The sociology of a nation, London: Routledge, 2001, $2^{\text {nd }}$ Edition.

Mayer, H. (2002) 'Einführung eines Ausländerwahlrechtes zu den Bezirksvertretungen in Wien', Österreichische Gemeinde-Zeitung, No. 8/2002, no page given.

Méndez Lago, M. (2005) 'The participation of non-national EU citizens in Spanish local elections', Paper prepared for the ESF/LESC-SCSS Exploratory Workshop: Citizens, non-citizens and voting rights in Europe, Edinburgh, 2-5 June 2005.

Neuman, G. (1992) "“We are the People”: Alien Suffrage in German and American Perspective', (1992) 13 Michigan Journal of International Law 259-335.

Nowak, M. and Lubich, A. (2005) Report on the Situation on Fundamental Rights in Austria in 2004, EU Network of Experts on Fundamental Rights (CFR-CDR).

Perchinig, B. (2005) Blocked by Constitution: How the Constitutional Court stopped municipal voting rights for Third Country Nationals in Vienna', Paper prepared for the ESF/LESC-SCSS Exploratory Workshop: Citizens, noncitizens and voting rights in Europe, Edinburgh, 2-5 June 2005.

Preuss, U. (2003) 'Citizenship and the German Nation', 7 Citizenship Studies 37-56.

Rubio-Marín, R. (2000) Immigration as a Democratic Challenge, Cambridge: Cambridge University Press.

Scheppele, K. (2004) 'Constitutional Ethnography: An Introduction’, (2004) 38 Law and Society Review 389-406.

Schmid-Drüner, M. (2006) ‘Germany’s New Immigration Law: A Paradigm Shift?’, 8 European Journal of Migration and Law 191-214.

Schuck, P. (2002) 'Some federal-state developments in immigration law', 58 NYU Annual Survey of American Law 387-390.

Shaw, J. (2007) The transformation of citizenship in the European Union. Electoral Rights and the Restructuring of European Political Space, Cambridge, Cambridge University Press.

Spiro, P. (2001) 'Federalism and immigration: models and trends', 167 International Social Sciences Journal 67-73.

Waldrauch, H. (2005) 'Electoral Rights for foreign nationals: a comparative overview', Paper prepared for the ESF/LESC-SCSS Exploratory Workshop: Citizens, non-citizens and voting rights in Europe, Edinburgh, 2-5 June 2005. 